\title{
Proposed minimal standards for the description of genera, species and subspecies of the Pasteurellaceae
}

Correspondence Henrik Christensen hech@kvl.dk

\author{
Henrik Christensen, ${ }^{1}$ Peter Kuhnert, ${ }^{2}$ Hans-Jürgen Busse, ${ }^{3}$ \\ Wilhelm C. Frederiksen ${ }^{4}$ and Magne Bisgaard ${ }^{1}$
}

\author{
${ }^{1}$ Department of Veterinary Pathobiology, The Royal Veterinary and Agricultural University, \\ 4 Stigbøjlen, DK-1870 Frederiksberg C, Denmark \\ ${ }^{2}$ Institute of Veterinary Bacteriology, Vetsuisse Faculty, University of Bern, Laenggass-Str. 122, \\ 3001 Bern, Switzerland \\ ${ }^{3}$ Institut für Bakteriologie, Mykologie und Hygiene, Veterinärmedizinische Universität, \\ Veterinärplatz 1, A-1210 Wien, Austria \\ ${ }^{4}$ Rødding Tværvej 3, 6630 Rødding, Denmark
}

Principles and guidelines are presented to ensure a solid scientific standard of papers dealing with the taxonomy of taxa of Pasteurellaceae Pohl 1981. The classification of the Pasteurellaceae is in principle based on a polyphasic approach. DNA sequencing of certain genes is very important for defining the borders of a taxon. However, the characteristics that are common to all members of the taxon and which might be helpful for separating it from related taxa must also be identified. Descriptions have to be based on as many strains as possible (inclusion of at least five strains is highly desirable), representing different sources with respect to geography and ecology, to allow proper characterization both phenotypically and genotypically, to establish the extent of diversity of the cluster to be named. A genus must be monophyletic based on 16S rRNA gene sequence-based phylogenetic analysis. Only in very rare cases is it acceptable that monophyly can not be achieved by $16 \mathrm{~S}$ rRNA gene sequence comparison. Recently, the monophyly of genera has been confirmed by sequence comparison of housekeeping genes. In principle, a new genus should be recognized by a distinct phenotype, and characters that separate the new genus from its neighbours should be given clearly. Due to the overall importance of accurate classification of species, at least two genotypic methods are needed to show coherence and for separation at the species level. The main criterion for the classification of a novel species is that it forms a monophyletic group based on 16S rRNA gene sequence-based phylogenetic analysis. However, some groups might also include closely related species. In these cases, more sensitive tools for genetic recognition of species should be applied, such as DNA-DNA hybridizations. The comparison of housekeeping gene sequences has recently been used for genotypic definition of species. In order to separate species, phenotypic characters must also be identified to recognize them, and at least two phenotypic differences from existing species should be identified if possible. We recommend the use of the subspecies category only for subgroups associated with disease or similar biological characteristics. At the subspecies level, the genotypic groups must always be nested within the boundaries of an existing species. Phenotypic cohesion must be documented at the subspecies level and separation between subspecies and related species must be fully documented, as well as association with particular disease and host. An overview of methods previously used to characterize isolates of the Pasteurellaceae has been given. Genotypic and phenotypic methods are separated in relation to tests for investigating diversity and cohesion and to separate taxa at the level of genus as well as species and subspecies. 


\section{Introduction}

The aim of the Bacteriological Code (International Code of Nomenclature of Bacteria) (Lapage et al., 1992; De Vos \& Trüper, 2000) is to outline recommendations and rules for naming of prokaryotes. It is not meant directly to deal with classification (General Consideration 4 of the Bacteriological Code; Lapage et al., 1992). However, it makes no sense to name a novel taxon without having considered its specific properties and evaluated how it differs from related taxa. To ensure the optimal circumscription of novel taxa to be named, it was therefore agreed to formulate minimal standards (Lessel, 1971), mentioned in Recommendation $30 \mathrm{~b}$ of the Bacteriological Code as being for the purposes of 'establishment of generic identity and for the diagnosis of the species' (Lapage et al., 1992).

For the same reasons, the aim of the minimal standards for the description of genera, species and subspecies of the family Pasteurellaceae is to ensure an unambiguous naming of novel as well as of existing taxa which will have to be reclassified. Erroneous nomenclature can pose major diagnostic problems and misunderstandings. According to Rule 56a of the Bacteriological Code, the Judicial Commission can remove names from the Approved Lists of Bacterial Names (Skerman et al., 1980) and subsequent validly published names (listed in the List of Prokaryotic Names with Standing in Nomenclature; Euzéby, 1997) by raising an Opinion. However, as a consequence of the Bacteriological Code and the Lists of Bacterial Names (Skerman et al., 1980), names can only be removed in very rare cases since 'names, once validly published, remain validly published' (Tindall, 1999). The only way to improve the naming standard is to perform solid taxonomic investigations at all levels from the selection of isolates for characterization to the appropriate use of methods for classification, identification and naming of taxa. The aim of the present paper is, based upon our present experiences, to provide scientists working on classification of the Pasteurellaceae with principles and guidelines in order to ensure a solid scientific standard of papers dealing with the taxonomy of taxa of Pasteurellaceae Pohl 1981.

\section{Current taxonomy of the family Pasteurellaceae}

The name Pasteurellaceae was effectively published by Pohl (1979) and validly published in 1981 (Pohl, 1981). Of the current genera of the Pasteurellaceae, only Pasteurella, Actinobacillus and Haemophilus were included in the Approved Lists of Bacterial Names (Skerman et al., 1980). Based upon DNA-DNA hybridizations, rRNA-DNA hybridizations and 16S rRNA gene sequence comparisons, all three genera were subsequently found to be polyphyletic (Mutters et al., 1989; De Ley et al., 1990; Dewhirst et al., 1992). As a first step toward reclassification, species found to be unrelated to the three genera Pasteurella, Actinobacillus and Haemophilus were informally excluded by writing the genus name of these species in brackets, leaving only sensu stricto taxa within these three genera (Mutters et al., 1989).
The family Pasteurellaceae currently (late 2006) includes 12 genera (Pasteurella, Actinobacillus, Haemophilus, Lonepinella, Mannheimia, Phocoenobacter, Gallibacterium, Histophilus, Volucribacter, Avibacterium, Nicoletella, Aggregatibacter) and 61 species with standing in nomenclature. The validly published names of members of Pasteurellaceae are listed in the online version of the List of Prokaryotic Names with Standing in Nomenclature (Euzéby, 1997), and a summary can be found with the homepage of the Taxonomic Subcommittee of the International Committee on Systematics of Prokaryotes (ICSP) that deals with the family (http://www.the-icsp.org/ taxa/Pasteurellaceaelist.htm). The current $16 \mathrm{~S}$ rRNA genederived consensus tree contains at least 14 groups and at least 16 monotypic taxa (Christensen et al., 2004; Olsen et al., 2005). Given this situation, more genera are expected to be named in the future. Reclassification of the many species excluded from Pasteurella sensu stricto, Actinobacillus sensu stricto and Haemophilus sensu stricto also represents a major challenge, especially in cases of the existence of closely related taxa.

Misidentification based upon phenotypic characterization is a frequent and serious problem among taxa of Pasteurellaceae. This is related either to insufficient methodologies, the lack of incorporation of type/reference strains or the fact that easily recognizable differences have not been present among taxa. Another problem is the presence of species that are clearly not members of the family, such as [Pasteurella] lymphangitidis and [Haemophilus] piscium. These taxa have already been shown to be affiliated with the Enterobacteriaceae and Aeromonas, respectively (De Ley et al., 1990; Frederiksen, 1991; Thornton et al., 1999), but formal changes have unfortunately not yet been proposed to prevent confusion.

Minimal standards for bacteria included in the Pasteurellaceae have been in the pipeline for a long time (Biberstein \& Zinneman, 1982; Wauters \& Mair, 1982). The present work was initiated by the ICSP Subcommittee on the taxonomy of the Pasteurellaceae in 2005 (Kuhnert \& Christensen, 2006) based on a draft prepared by Wilhelm Frederiksen. Some of the principles have been discussed in a taxonomic note (Christensen et al., 2001). The main issue of the note was to ensure a wide diversity of the bacterial strain collection used for naming novel taxa, and it was proposed to incorporate such recommendations in the Bacteriological Code. This suggestion was not followed by the ICSP, although the suggestions were recommended to be followed as 'best practice' (Saddler, 2005).

\section{Minimal standards}

The classification of the Pasteurellaceae is in principle based on a polyphasic approach. Polyphasic taxonomy has been outlined by Vandamme et al. (1996) and Gillis et al. (2005). The strategy in modern polyphasic taxonomy is first to estimate the different levels of taxonomic discrimination to be covered and then to choose the techniques accordingly. 
There is no universal strategy that can be employed in all polyphasic studies, and polyphasic taxonomy is purely empirical. The taxonomic resolution of many techniques can differ depending on the bacterial groups studied. The minimal requirements for obtaining useful polyphasic data are a preliminary screening for groups of similar strains, and various typing methods can be used for this and then to determine the phylogenetic position of these groups, measure the relationship between the groups and their closest neighbours and finally to collect various descriptive data preferentially on different aspects of the cell (Gillis et al., 2005).

It is the aim of the minimal standards briefly to review previous experiments with methods used for characterization, classification, identification and naming of taxa of the Pasteurellaceae and briefly to outline principles for combinations of methods to allow proper classification, identification and naming of genera, species and subspecies. As already mentioned, strict rules cannot be given for characterization and classification, so we only present our recommendations. Previously, a novel taxon with candidate status to be named was recognized by phenotype and the classification was subsequently supported by genetic studies including DNA-DNA hybridization that corroborated the phenotypic conclusions. The current approach to taxonomic investigations is to recognize the identity of a novel group and its differences from other groups by genotype and then to search for phenotypic characters that enable its separation in relation to classification and identification. Approaches based on sequencing of certain genes are very important for defining the borders of a taxon. However, the characteristics that are common to all members of the taxon and which might be helpful for separating it from related taxa must also be identified. Sequencing might be a start, but a proper characterization of both phenotype and genotype is a prerequisite.

\section{Selection of isolates}

It is important to include a sufficient number of isolates covering the diversity of taxa to be named. The experimental documentation for the existence of species at the genotypic level 'requires analysis of large populations of each candidate species and not just one or a few reference isolates' (Hanage et al., 2005). A certain minimum number of strains has also been mentioned in other minimal standards (Graham et al., 1991; Freney et al., 1999; Bernardet et al., 2002). For members of the Pasteurellaceae, descriptions have to be based on as many strains as possible (inclusion of at least five strains is highly desirable), representing different sources with respect to geography and ecology to allow proper characterization both phenotypically and genotypically, to establish the extent of diversity of the cluster to be named (Christensen et al., 2001). Naming of novel taxa associated with serious disease and/or lesions should be considered irrespective of whether they meet these requirements as to geographical and ecological diversity or not, in order to account for and to investigate their pathogenicity. The phenotypic and genotypic diversity of isolates should be confirmed by relevant methods, examples of which are listed in Table 1.

It is highly recommended to keep all isolates, including those that can not be properly identified. The bacteria should be lyophilized or frozen at $-80^{\circ} \mathrm{C}$ in order to avoid repeated subculturing of the original isolates. A special $7.5 \%$ glucose serum medium (Lapage \& Redway, 1974) is recommended for storage of the more sensitive cultures at $-80^{\circ} \mathrm{C}$. The glucose solution is sterilized by filtration and mixed with sterile calf serum and stored at $-20^{\circ} \mathrm{C}$. Bacteria to be frozen are subcultured from a single colony on blood agar and, following overnight incubation at $37^{\circ} \mathrm{C}, 1 \mathrm{ml}$ of the freeze medium is used for suspension of the overnight growth. Storage in liquid nitrogen can be used when facilities for freezing or freeze-drying are not available.

\section{Taxonomic investigation at the family level}

Based on 16S rRNA gene sequence comparisons, the Pasteurellaceae is currently classified as the only member of the order Pasteurellales. This order is included within the class Gammaproteobacteria of the phylum Proteobacteria (Brenner et al., 2005). The first indication that a taxon belongs to the Pasteurellaceae will probably come from comparison of $16 \mathrm{~S}$ rRNA gene sequences. Within the family, species currently share $16 \mathrm{~S}$ rRNA gene sequence similarities of more than $89 \%$ (Christensen, 2005). The closest similarity outside the family has been to taxon 37 of Bisgaard (without family affiliation at present), with $87 \%$, whereas similarities to the families Enterobacteriaceae and Vibrionaceae are around 85 and $87 \%$, respectively (data not shown).

With respect to phenotype, members of the family Pasteurellaceae have been characterized as Gram-negative, non-motile rods, coccoids or filaments with aerobic, microaerobic or facultatively anaerobic respiration and chemo-organotrophic metabolism and with the ability to reduce nitrate (Bisgaard, 1993; Olsen et al., 2005). The homogeneous nature of the profiles of phospholipids and cellular fatty acids do not allow further separation below the family level (Mutters et al., 1993; Olsen et al., 2005). In addition to these common characteristics of the family, 21 physiological and biochemical tests have been found to be conserved for the 12 named genera (Table 2). Currently, it is unknown whether they are conserved for the whole family, including all unnamed taxa.

Few characters allow clear separation from members of the related families Enterobacteriaceae and Vibrionaceae. The lack of motility and the (mainly) oxidase- and phosphatasepositive test results separate members of the Pasteurellaceae from most members of the Enterobacteriaceae, which are motile and oxidase- and phosphatase-negative. The habitat of warm-blooded animals, lack of motility and lack of tolerance to high salt concentrations separate members of the Pasteurellaceae from most members of the Vibrionaceae. 
Table 1. Overview of tests previously used for investigation of diversity, cohesion and separation of taxa of the Pasteurellaceae

Further details of the tests are available in the appendix. Horizontal rules separate methods used for investigation of diversity and cohesion/ separation.

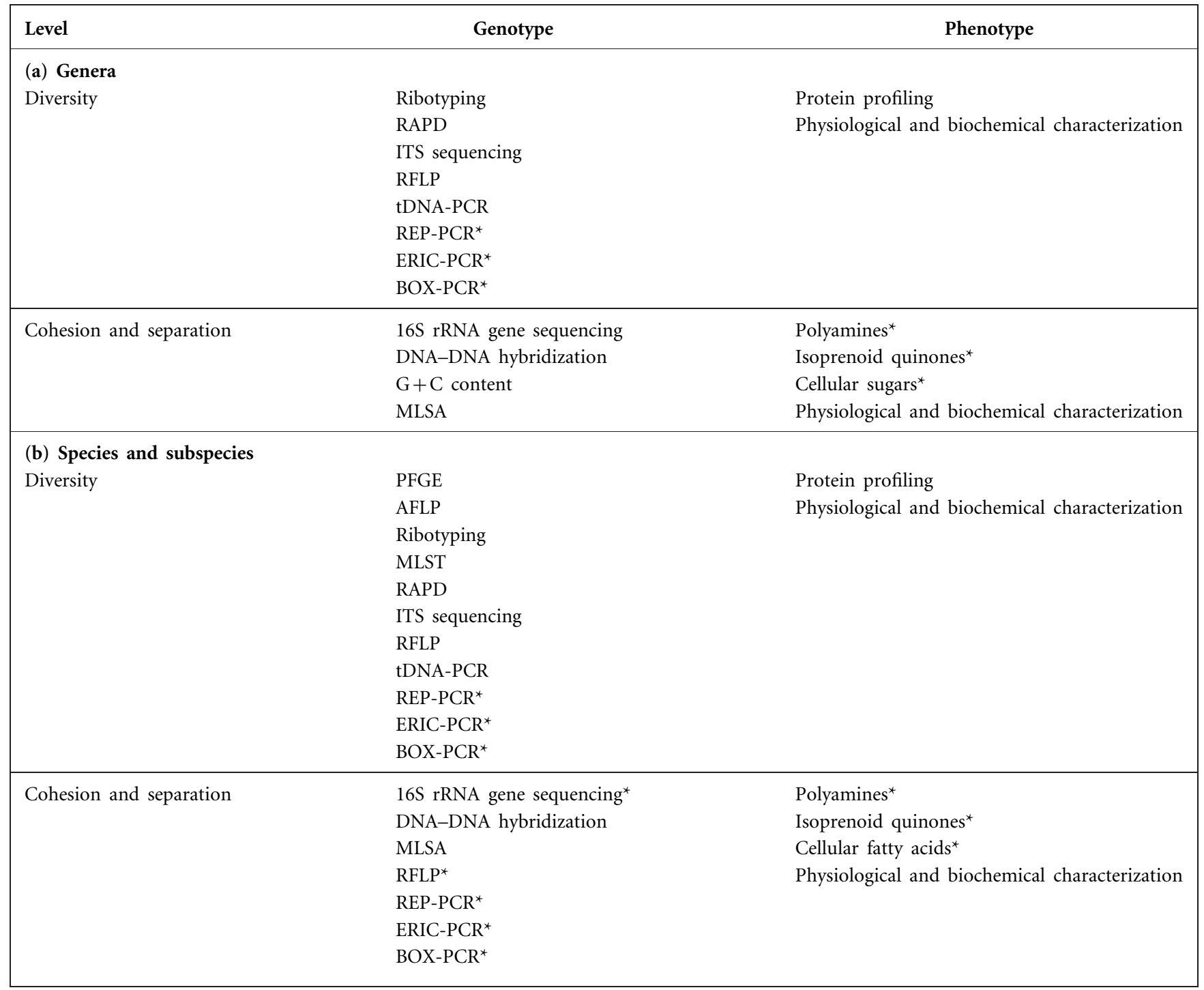

${ }^{\star}$ Tests are not suitable for all members of Pasteurellaceae or they have not been tested for this purpose with all members of the family.

\section{Taxonomic investigation at the genus level}

A new genus should be formed only when it is clearly needed. New genera are formed based on unnamed taxa or by reclassification of clades within polyphyletic genera which are clearly separate from the type species of the genus. The diversity of strains investigated should be documented as stated above and characterization should include both genotypic and phenotypic methods (Table 1a). In order to classify and name a new genus, the type strains of all related taxa should be included for comparison, which requires at least all type species of the genera of the Pasteurellaceae, in order to provide descriptions that are sufficiently detailed to allow differentiation from these genera.
Special requirements for genotypic investigations at the genus level to document cohesion and separation. A genus must be monophyletic based on $16 \mathrm{~S}$ rRNA gene sequence-based phylogenetic analysis. Only in very rare cases is it acceptable that monophyly can not be achieved by $16 \mathrm{~S}$ rRNA gene sequence comparison (see the problems with Actinobacillus capsulatus described below). In these cases, a multilocus sequence analysis (MLSA) approach needs to be used to indicate monophyly. The $16 \mathrm{~S}$ rRNA gene sequence similarity is predominantly below $\sim 95 \%$ between genera of the Pasteurellaceae. Recently, the monophyly of genera has been confirmed by sequence comparison of infB and $r p o B$ genes, with genera showing similarity above $85-88 \%$ at the nucleotide sequence level 
Table 2. Common physiological and biochemical traits for members of the 12 named genera of the Pasteurellaceae

Further details of the tests are available in the appendix. Data were taken from Mannheim (1989) and Christensen (2005).

\begin{tabular}{|l|}
\hline Tests \\
\hline Gram reaction, motility, Simmons' citrate agar, acid formation from mucate, basic reaction from \\
malonate, nitrate reduction, KCN, gas formation from nitrate, arginine dihydrolase, phenylalanine \\
deaminase, $\alpha$-mannosidase, hydrolysis of gelatinase and Tweens 20 and 80 , acid formation from \\
meso-erythritol, adonitol, $(-)$-L-xylose, $(+)$-D-fucose, $(-)$-L-sorbose, $(+)$-D-melezitose, \\
$(+)$-D-turanose and $\beta$ - $\mathrm{N}-\mathrm{CH}_{3}$-glucosamid \\
Alanine aminopeptidase, acid formation from $(+)$-D-glucose \\
\hline
\end{tabular}

(Angen et al., 2003; Korczak et al., 2004; Nørskov-Lauritsen et al., 2004; Kuhnert et al., 2004). Justification for affiliation of a taxon to a genus will therefore be justified in most cases with more than $90 \%$ infB and/or $r p o B$ gene similarity to established species within the genus if the relationship is also supported by other characteristics. However, the 'break-point' might change if other regions of the infB and $r p o B$ gene sequences are analysed, and phylogenetic analysis will be needed to verify affiliation with a particular genus including taxa with borderline similarities below $90 \%$.

In addition, a sequencing approach for the three genes $r e c N$, rpo $A$ and $t h d F$ has been established and validated for the calculation of whole-genome relatedness (Kuhnert \& Korczak, 2006). It is well known that DNA reassociation values do not directly reflect the actual degree of DNA sequence similarity (Stackebrandt, 1992). However, for selected taxa, it has been shown that genome similarity can be estimated by a formula from representative genes, and these genome similarity values can be related to the degree of DNA reassociation. Results obtained so far have identified genus boundaries around a calculated genome similarity value of 0.4 . The genome similarity value of 0.4 is in agreement with past results for the three oldest genera based upon DNA-DNA hybridizations, where species belonging to the same genus have been linked by DNA reassociation values above $55 \%$ (Mutters et al., 1989). Additional investigations, however, might change these values.

Special requirements for phenotypic investigations at the genus level to document cohesion and separation. In principle, a new genus should be recognized by a distinct phenotype and characters that separate the new genus from its neighbours should be given clearly. The current conserved characters for genera are listed in Table 2 and characters used for separation of genera have been stated, for example by Blackall et al. (2005). Generally, chemotaxonomic characteristics are most useful for differentiation of genera. However, fatty acid and polar-lipid profiles are highly homogeneous among representatives of the Pasteurellaceae. On the other hand, both polyamine patterns and quinone systems have been shown to exhibit some degree of variability among representatives of the family and appear to be useful for classification of at least some genera, including Lonepinella, Pasteurella sensu stricto and Avibacterium (Osawa et al., 1995; Busse et al., 1997; Kainz et al., 2000). However, this approach needs to be evaluated in more detail for other genera and clades within the family.

Gallibacterium as an example of naming a new genus. To illustrate a typical taxonomic investigation at the genus level, Gallibacterium (Christensen et al., 2003) will briefly be summarized. The new genus Gallibacterium was formed to accommodate the species [Pasteurella] anatis, the taxon 'Actinobacillus salpingitidis' and the group formerly known as avian [Pasteurella] haemolyticalike organisms. PFGE first documented that strains representing 15 biovars of the avian [Pasteurella] haemolytica'Actinobacillus salpingitidis' complex were genotypically divergent. The diversity in plasmid profiles also confirmed that the strains were genotypically different. Amplified fragment length polymorphism (AFLP) fingerprinting identified strains as genotypically different and confirmed the results obtained by phylogenetic analysis of 16S rRNA genes and DNA-DNA hybridization (see below). Strains included in Gallibacterium formed a monophyletic group by $16 \mathrm{~S}$ rRNA gene sequence comparison. Two monophyletic groups within Gallibacterium were recognized. The $16 \mathrm{~S}$ rRNA gene sequence similarities between the two groups were 95.7-97.1\%. The highest $16 \mathrm{~S}$ rRNA gene sequence similarity outside the genus was $94.6 \%$, to taxon 3 of Bisgaard, just around the general value of $95 \%$. With $16 \mathrm{~S}$ rRNA gene sequence similarities between the two groups slightly above $97 \%$, DNA-DNA hybridizations were needed. The reason for this is that, for species with more than $97 \%$ similarity, ' $16 \mathrm{~S}$ rRNA sequence identity may not be sufficient to guarantee species identity' (Fox et al., 1992). Results of DNA-DNA hybridizations showed 29 strains of one of the $16 \mathrm{~S}$ rRNA groups to link at $79-100 \%$ DNA reassociation. The three strains of the other 16S rRNA group were linked at $87 \%$ DNA reassociation. The bacteria shared all the common phenotypic characters with other genera-like groups of the Pasteurellaceae as reported in Table 2. In addition, a further 36 characters were shared by this genus. Variations were observed with respect to 11 physiological/ biochemical characters. The genus Gallibacterium can be separated from other genera of the Pasteurellaceae by 
differences in 14 characters. However, separation from members of Avibacterium (Avibacterium gallinarum, Avibacterium volantium and Avibacterium avium) was only possible at the species level. Separation from the other genera of the Pasteurellaceae was possible by at least two characters. Gallibacterium anatis was selected for the type species of the genus since it was the only species with a validly published name within this genus. Gallibacterium anatis represented one of the genotypic groups documented by $16 \mathrm{~S}$ rRNA and DNA-DNA hybridization. However, the other group could not be separated phenotypically and was left as a unnamed genomospecies of Gallibacterium.

\section{Taxonomic investigation at the species level}

The species represents the main taxonomic category in classification, and the formation or reclassification of species must be well justified. The diversity of strains investigated should be secured according to the criteria listed under 'Selection of isolates' and at least two genotypic and two phenotypic methods addressing different principles should be used for characterization (Table 1b). Physiological and biochemical tests are considered in this context as one method, and relevant tests need to be carried out. 16S rRNA gene sequence analyses should be carried out on strains representing the genetic diversity. Other genotypic methods should be applied if the $16 \mathrm{~S}$ rRNA gene sequence similarities to established species are higher than $97.0 \%$.

In order to classify and name a novel species, the type strains of all related taxa should be included for comparison. In addition, comparative studies have to be performed, including reference strains that represent neighbouring species, in order to give descriptions that are sufficiently detailed to allow differentiation from these neighbours (Christensen et al., 2001). The characters that differentiate the novel species from its neighbours must be given clearly.

\section{Requirements for genotypic investigations at the spe- cies level to document cohesion and separation. Due} to the overall importance of accurate classification of species, at least two genotypic methods are needed to show coherence and for separation at the species level. The main criterion for the classification of a novel species is that it forms a monophyletic group based on 16S rRNA gene sequence-based phylogenetic analysis. However, some groups might also include closely related species since '16S rRNA sequence identity may not be sufficient to guarantee species identity' (Fox et al., 1992). In these cases, more sensitive tools for genetic recognition of species should be applied, such as DNA-DNA hybridizations. The general rule is that 16S rRNA sequence similarity higher than $97 \%$ between different species candidates implies that DNA-DNA hybridization or comparable methods should be applied (Stackebrandt \& Goebel, 1994; Stackebrandt et al., 2002). 16S rRNA gene sequence comparison, however, may be misleading. By phylogenetic analysis of 16S rRNA gene sequences, Actinobacillus capsulatus was excluded from Actinobacillus sensu stricto and found to be closely related to [Haemophilus] paracuniculus. However, evidence from DNA-DNA hybridizations and comparison of five housekeeping gene sequences showed that this species belongs genotypically to Actinobacillus sensu stricto. This affiliation is also phenotypically justified (Kuhnert et al., 2007).

The comparison of housekeeping gene sequences has recently been used for genotypic definition of species. In the study of Nørskov-Lauritsen et al. (2005), four genes were used for MLSA comparison to describe the novel species Haemophilus pittmaniae, supporting DNA-DNA hybridization results. Three of the housekeeping genes were selected from the multilocus sequence typing (MLST) study of Haemophilus influenzae (Meats et al., 2003). In MLST, sequence types are considered as different when one or more nucleotides differ between two sequences. The sequence types are numbered arbitrarily independently of the number of nucleotide differences. In MLSA, sequences are compared by similarity and, in addition, phylogenetic analysis is carried out on the basis of similarity matrices or directly from the sequences. MLSA is most suitable for species separation, whereas MLST seems best suited for investigation of species diversity (Maiden et al., 1998; Gevers et al., 2005) (Table 1b).

If species were defined only on the basis of monophyly of DNA sequences (phylogenetic classification), it would be impossible to set up guidelines for the level of species separation, and therefore cut-off values in relation to similarities have been defined. The classical method for defining species of the Pasteurellaceae at the genotypic level has been DNA-DNA hybridization. In contrast to most other prokaryotic taxa, where the threshold value for species affiliation is $70 \%$, species of the Pasteurellaceae have mostly been defined by showing DNA reassociation values of $80-85 \%$ as measured by the spectrophotometric method (Mutters et al., 1989; Christensen et al., 2002, 2005). To avoid the work required for very laborious full-matrix hybridizations, hybridizations are normally carried out between the type strain and selected strains. This means that all possible DNA reassociation values have not been tested. In cases where full-matrix hybridizations have been performed, a few strains have occasionally been found to bind at lower levels (Christensen et al., 2003). The consensus seems to be to leave such strains within the species if they are linked to the type strain through a high degree of DNA reassociation with other strains. The opposite situation, in which a single isolate bridges two candidate species, has also been observed, underlining the risk associated with performing only selected DNA-DNA hybridizations (Angen et al., 1999). Based on the work of Zeigler (2003), Kuhnert \& Korczak (2006) proposed that sequence comparison of the three genes $r e c N, r p o A$ and thdF could replace DNA-DNA hybridizations. They further showed that even sequencing of a single gene, $\operatorname{rec} \mathrm{N}$, might serve this purpose. Further investigations are needed before final conclusions can 
be made as to the possibility of replacing DNA-DNA hybridizations with this method. DNA-DNA hybridization experiments are obligatory for the classification of novel species where the $16 \mathrm{~S}$ rRNA divergence is low. However, if the promising results of Kuhnert \& Korczak (2006) can be confirmed in extended studies involving a broader collection of strains, MLSA may substitute for DNA-DNA hybridization in the future. This will only become true if several strains of every species are tested to determine the threshold value for species affiliation.

Requirements for phenotypic investigations at the species level to document cohesion and separation. Members of a species must share a common set of phenotypic characteristics. In order to separate species, phenotypic characters must also be identified in order to recognize them, and at least two phenotypic differences from existing species should be identified to name a novel species if the study is based on examination of at least five strains of the novel taxon. If fewer strains are included, more phenotypic differences from established species should be identified. However, a single phenotypic character might be enough in cases of clear genotypic differences demonstrated by several methods.

To illustrate when 16S rRNA gene sequence analysis is insufficient for species-level separation and where it might be used, the naming of Actinobacillus arthritidis (Christensen et al., 2002) and Aggregatibacter actinomycetemcomitans (Nørskov-Lauritsen \& Kilian, 2006) are given as respective examples. The example of Gallibacterium just mentioned in relation to genus level classification also includes a discussion of this issue.

Actinobacillus arthritidis. This species was established based on investigation of 12 equine strains that had previously been classified as Actinobacillus lignieresii. 16S rRNA gene sequence analysis showed $99.6 \%$ similarity between two selected strains of Actinobacillus arthritidis, the nearest neighbour being Actinobacillus ureae, with 98.0-98.3\% similarity. Another group of six equine strains, Actinobacillus genomospecies 2, showed 97.7-97.9\% similarity to Actinobacillus arthritidis. Since the similarity was above $97 \%$, DNA-DNA hybridizations were necessary to document the species status. The two strains of Actinobacillus arthritidis showed $83 \%$ DNA reassociation and were most closely related to Actinobacillus genomospecies 2 (sorbitol-negative group), with $72-76 \%$ DNA reassociation. Previous studies had shown DNA binding values between the type strains of Actinobacillus arthritidis and Actinobacillus ureae to be $44 \%$ (Escande et al., 1984), and DNA-DNA hybridization of $50 \%$ was reported between reference strain CCUG 15571 of Actinobacillus genomospecies 2 and the type strain of Actinobacillus hominis (Friis-Møller et al., 2001). DNA-DNA hybridization was therefore able to separate these novel species/genomospecies from existing members of Actinobacillus sensu stricto. Actinobacillus arthritidis and
Actinobacillus genomospecies 2 might be separated only by acid formation from sorbitol; Actinobacillus genomospecies 2 was therefore left unnamed, awaiting future phenotypic characters able to separate the two.

Aggregatibacter actinomycetemcomitans. The $16 \mathrm{~S}$ rRNA gene sequence similarity between this species and other species of Aggregatibacter is $95.9 \%$ or less, which justifies separate species status. For historical reasons, numerous DNA-DNA hybridizations have been carried out with this species, documenting unequivocally its unique species status, in addition to recent investigations by MLSA (Nørskov-Lauritsen \& Kilian, 2006).

\section{Taxonomic investigation at the subspecies level}

Solid biological and diagnostic reasons should exist to separate species into subspecies. So far, the subspecies category has been used only with Pasteurella multocida and Actinobacillus equuli (Mutters et al., 1985; Christensen et al., 2002), and our present experience is built on these two cases. We recommend the use of the subspecies category only for subgroups associated with disease or similar biological characteristics.

Sufficient diversity of strains investigated should be secured according to the criteria listed under 'Selection of isolates' and several genotypic and at least one phenotypic method should be used to demonstrate the diversity. In order to classify and name a novel subspecies, the type strains of all related species (or subspecies) should be included for comparison. In addition, comparative studies including reference strains that represent neighbouring species (or subspecies) should be carried out, in order to generate descriptions that are sufficiently detailed to allow separation from these neighbours. Characteristics that separate the novel subspecies and its neighbours must be given clearly.

The consensus for documentation of cohesion and separation of subspecies of members of the Pasteurellaceae at the genotypic level parallels those given for species separation. In addition, the genotypic groups must always be nested within the boundaries of an existing species. Phenotypic cohesion must be documented at the subspecies level and separation between subspecies and related species must be fully documented as well as association with particular disease and host.

\section{Identification}

A prerequisite for naming taxa at the genus, species and subspecies level is the ability to separate and identify isolates by methods available outside a specialized laboratory. In most cases, characters for identification are available from the classification process. However, identification does not need to be based on the same methods used in classification. Commercial identification systems should be used only if reliable databases are available, particularly with species expected to cause differential diagnostic problems. 
Gas-chromatographic analysis of methyl esters of cellular fatty acids (CFA-FAME) is valuable for quality control of reference strains of members of the family in culture collections (http:// www.ccug.gu.se/default.cfm?navID $=252$ ). In contrast to commercial tests, DNA-based methods have no proprietary rights (fees might be paid in commercial laboratories). They are open and highly reproducible. Therefore, PCR tests should be developed and included since they are now available in non-specialist laboratories and are easily standardized and they demand less work than the classical phenotypic tests. The same holds true for methods using DNA sequencing (Gautier et al., 2005; Cattoir et al., 2006). In addition, some commercial laboratories now offer DNA sequencing at relatively low cost.

\section{Selection of type strains, deposition with culture collections and submission of sequences and proposal for taxonomic changes}

The type strain should always be selected to represent a 'typical' strain of the taxon to be named, although there is no formal requirement for this. A precondition for naming a novel taxon, however, is that the type strain is deposited with at least two culture collections in different countries, to allow public exchange (De Vos \& Trüper, 2000). It is important that submissions of sequences are not annotated with premature Latin names, since these will be incorporated in the database and search functions (taxonomy browser at NCBI) (Wheeler et al., 2004). For example, the name 'Mannheimia succiniciproducens' is now used with the entire genomic sequence deposited in the international sequence databases although the name is not validly published owing to the failure to deposit the type strains in culture collections with public access. It is the responsibility of the sequence depositor to correct the name given with the deposited sequence. Proposals of taxonomic changes should preferably be published in journals dealing specifically with bacterial taxonomy.

\section{Methods}

An overview of methods used previously to characterize isolates of Pasteurellaceae has been given in Table 1. This table separates genotypic and phenotypic methods in relation to tests for investigating diversity and cohesion and to separate taxa at the level of genus (Table 1a), as well as species and subspecies (Table $1 \mathrm{~b}$ ). The biochemical and physiological methods can be used to test diversity, cohesion and separation. However, some are better suited to the investigation of diversity and others for investigation of cohesion/separation. The list does not exclude alternative methods to be used in the future.

Genotyping. Methods for investigation of the genotypic diversity of isolates are normally more open than those for investigation of cohesion and separation of isolates. Methods for initial investigation of genotypic diversity of isolates are normally chosen to provide an appropriate level of resolution with respect to the categories genus, species and subspecies. Results obtained provide the background for investigation of cohesion of isolates and separation of taxa.

Phenotyping. The 'traditional' physiological and biochemical tests are often poorly described, since it is frequently assumed that they are performed according to the same overall standards in laboratories around the world. However, factors such as type of test, nature and composition of media, $\mathrm{pH}$ range of indicators and time of incubation are frequent variables that may give rise to different results between laboratories. To provide an example of a set of standard conditions used for phenotypic characterization, we have adopted the protocols used in two Danish and one German laboratory for decades (Mannheim, 1989; M. Bisgaard and W. C. Frederiksen, unpublished), resulting in highly reproducible and comparable results (see Angen et al., 1997a). Other methods could be used, but they should be listed with a similar level of detail, or with references given to descriptions of the tests. Special conditions for culturing of members of the Pasteurellaceae should be accounted for and reference strains should be included in order to demonstrate that the same results are obtained. The methods described in Table 1 have mainly been adopted from Bisgaard et al. (1991) with reference to Barrow \& Feltham (1993). Consultation of the major publications dealing with phenotypic characterization of members of the Pasteurellaceae is further recommended (Kilian, 1976; Kilian \& Frederiksen, 1981; Sneath \& Stevens, 1985; Mannheim, 1989). The incubation temperature is $37^{\circ} \mathrm{C}$ for all isolates unless otherwise stated. Some members of the Pasteurellaceae may need increased atmospheric $\mathrm{CO}_{2}$ for optimal growth. Compared with the conventional use of these tests, the observation time has been extended up to 2 weeks for isolates with negative reactions. As a control for the methods used, reference strains with known reaction patterns should always be included with the phenotypic assays. In addition, batch control of media should be carried out regularly. Only methods known to be problematic have been described in detail in the appendix. However, the entire 'battery' of phenotypic tests might also be required for taxonomic investigations (Table 1). Without prior information, this battery of around 80 tests is used to investigate diversity and to document cohesion and to separate taxa at the genus, species and subspecies levels. Chemotaxonomic methods are used to investigate cohesion and usually to separate genera. Methods used less frequently for taxonomic investigation include serotyping and related tests based on immunological reactions, multilocus enzyme electrophoresis, determination of metabolic products and animal pathogenicity testing (Snipes \& Biberstein, 1982; Mutters et al., 1993; Schmid et al., 1991; Angen et al., 1997b; Blackall et al., 1998).

Species are defined as positive or negative for a particular trait when more than $90 \%$ of strains show this particular characteristic. Therefore, phenotypic profiles used to circumscribe species might change if additional strains of 
a species are analysed, in particular if the selection of isolates has been biased. The frequency of aberrant strains represents another complicating factor. In a species with a high frequency of variability, strains with fewer characteristics will score as positive or negative compared with species with less variability.

\section{Appendix}

RAPD. 'Rapid' or randomly amplified polymorphic DNA has been used for genetic characterization in relation to taxonomic investigations of [Pasteurella] aerogenes, [Pasteurella] mairii and [Actinobacillus] rossii (Christensen et al., 2005). This analysis is included mainly to document the diversity of strains to be characterized further by genotypic methods, which are used to separate and show cohesion at the genus and species levels (Table 1).

PFGE. Pulsed-field gel electrophoresis was used in the investigation of Gallibacterium (Christensen et al., 2003). PFGE is considered one of the most sensitive methods for genotypic separation of isolates. However, this will be a drawback when highly diverse taxa are investigated, since they cannot always be categorized within distinct clusters. This assay is included to document the diversity of strains to be characterized further by genotypic methods.

AFLP. Amplified fragment length polymorphisms have been used for investigation of Gallibacterium (Christensen et al., 2003). The heavy workload required for PFGE might be relieved by the automation associated with AFLP, although it requires more specialized equipment.

Ribotyping. Ribotyping is restriction enzyme analysis followed by visualization of fragments containing ribosomal genes by hybridization with a labelled probe derived from rRNA or rRNA genes. This method has been used in taxonomic investigation of Mannheimia (Angen et al., 1997b)

RFLP. Restriction fragment length polymorphism analysis of PCR products generated from $16 \mathrm{~S}$ rRNA or $23 \mathrm{~S}$ rRNA genes. Similarities in the banding patterns achieved by RFLP are taken as evidence for assignment of strains to the same species (Kainz et al., 2000; Nørskov-Lauritsen \& Kilian, 2006). On the other hand, banding patterns without any similarity do not necessarily demonstrate that two strains are members of different species.

Other PCR-based methods. ITS (internal spacer region between the $16 \mathrm{~S}$ and $23 \mathrm{~S}$ rRNA genes), tDNA-PCR, REP-PCR, ERIC-PCR and BOX-PCR have been used to investigate diversity within Pasteurella, Gallibacterium and Mannheimia (Fussing et al., 1998; Kainz et al., 2000; Christensen et al., 2003; Catry et al., 2004). Most applications of these methods have been limited to single studies; however, all methods might potentially be of use in testing the diversity of isolates. REP-PCR, ERIC-PCR and BOX-PCR are only suitable for assignment to a certain species based on obvious similarities in the banding patterns. On the other hand, banding patterns without any similarity do not necessarily demonstrate that two strains are members of different species.

DNA-DNA hybridization. The spectrophotometric, S1 nuclease, hydroxyapatite and microwell methods have all been used with members of Pasteurellaceae (Mutters et al., 1985; Møller et al., 1996; Friis-Møller et al., 2001; Christensen et al., 2002). The accuracy of DNA-DNA hybridization is considered equivalent to whole-genomic sequence comparison and MLSA (Gevers et al., 2005). Due to the large amount of work involved, in most cases hybridizations have only been performed between the type strain and selected strains within or between species. Results gained from full-matrix hybridizations (all strains hybridized against each other) are preferred. However, hybridization of selected strains with the type strain of the species is sufficient.

DNA G+C content. Determination of the $\mathrm{G}+\mathrm{C}$ content (expressed as $\mathrm{mol} \%$ ) is mandatory only for the type strain of the type species of a novel genus. The $\mathrm{G}+\mathrm{C}$ content has been measured by the spectrophotometric method (see Mutters et al., 1985) and by HPLC (Møller et al., 1996). Recently, a new method for estimation of the $\mathrm{G}+\mathrm{C}$ content of genomes has been published based only on the DNA sequence of a single gene ( $f t s Y$ ) (Fournier et al., 2006). High resolution was achieved using three genes $(\operatorname{recN}, \quad r p o A$, thdF) as shown by Kuhnert \& Korczak (2006). These DNA sequence-based alternatives have not yet been recognized as an adequate substitute for conventional methods of $\mathrm{G}+\mathrm{C}$ determination.

$16 S$ rRNA gene sequencing. Almost all species or species-like taxa of the Pasteurellaceae have so far been characterized by $16 \mathrm{~S}$ rRNA gene sequence analysis, and deposited sequences are available from the International Nucleotide Sequence Database Collaboration and similar databases (Benson et al., 2006; Cochrane et al., 2006; Okubo et al., 2006). Searches for DNA sequences in these databases are normally performed by BLAST (Altschul et al., 1997) or FASTA (Harte et al., 2004). 16S rRNA gene sequence accession numbers for type and reference strains are listed at the homepage of the ICSP Taxonomic Subcommittee dealing with the Pasteurellaceae (http:// www.the-icsp.org/taxa/Pasteurellaceaelist.htm). Determination of 16S rRNA gene sequences is often routinely carried out for atypical or unidentifiable isolates in many laboratories. Alternatively, it is possible to have $16 \mathrm{~S}$ rRNA gene sequencing done in specialized commercial laboratories. 16S rRNA gene sequences are used for phylogenetic inference and are compared in relationship to similarity by pairwise alignment. To determine the degree of pairwise similarity precisely, appropriate software should be used such as the EMBOSS program WATER (Rice et al., 2000). The pairwise similarity output from BLAST is not appropriate. By using FASTA, the pairwise similarity values obtained from the EBI database server can be used directly. Multiple alignments can be constructed by CLUSTAL $\mathrm{X}$ or similar software (Thompson et al., 1997) and sequence alignments can be improved according to secondary structure utilizing the ARB program package (Ludwig et al., 2004). The variation between taxa within a large family like Pasteurellaceae is probably too complex to allow phylogenetic inference based only on neighbour-joining analysis (Ludwig \& Klenk, 2001). As a minimum for improvement, bootstrap analysis should always accompany phylogenetic results. It should be mandatory not only to calculate neighbour-joining trees, but also to do maximum-parsimony and maximum-likelihood phylogenetic analysis to demonstrate the same topology.

MLST and MLSA (housekeeping gene sequencing). MLST is used to investigate the intraspecies population structure, and such investigations have been performed with Haemophilus influenzae and Pasteurella multocida (Meats et al., 2003; Davies et al., 2004). Further information can be found at the MLST database server (http://www.mlst.net/databases/). With the purpose of documenting separation as well as cohesion of taxa, DNA sequence comparison of housekeeping genes has been used for phylogenetic investigation of selected groups of Pasteurellaceae (MLSA). The housekeeping gene sequences can be searched, obtained and analysed by the same tools listed for 16S rRNA gene sequences. With high variation between DNA sequences as observed between genera of the Pasteurellaceae, it might be necessary to perform the phylogenetic comparisons at the protein level (Christensen et al., 2004).

Polyamines. Previous knowledge of polyamines was reviewed by Tabor \& Tabor (1985). Approximately two-thirds of the named species and numerous unnamed taxa of the Pasteurellaceae have been 
characterized and the polyamines have been found to be specific in at least some cases at the genus level (Pasteurella sensu stricto, Avibacterium, Actinobacillus sensu stricto) and in some cases at the species level, but it appears possible that this specificity is caused by examination of only one representative of a separate, not yet described genus (Osawa et al., 1995; Busse et al., 1997). Procedures for extraction and analysis of polyamines have been described by Busse et al. (1997). However, data on reproducibility and withinspecies variation are needed for clarification of the impact of the generated results.

Cellular sugars. Analysis of cellular sugars has been shown to be potentially useful for separation of genera and species (Mutters et al., 1993; Olsen, 1993). However, the method has rarely been used in taxonomic investigations.

Isoprenoid quinones. Isoprenoid quinone patterns have been used to show cohesion within Pasteurella sensu stricto and Avibacterium and have the potential to separate these taxa from other genera (Mutters et al., 1993; Kainz et al., 2000).

Protein profiling. This method has been used to show diversity within certain avian taxa (Bisgaard et al., 1993).

Physiological and biochemical tests. These tests include catalase, oxidase, the Hugh \& Leifson test, Simmons' citrate, acid from mucate, basic reaction from malonate, $\mathrm{H}_{2} \mathrm{~S} / \mathrm{TSI}$, KCN, VogesProskauer, methyl red test, reduction of nitrate and gas formation from nitrate, urease, alanine aminopeptidase, arginine dihydrolase, lysine decarboxylase, ornithine decarboxylase, phenylalanine deaminase, indole, alkaline phosphatase, gelatinase, hydrolysis of Tweens 20 and 80, growth on MacConkey agar, pigment formation, gas from glucose and aesculin hydrolysis.

$\mathrm{V}$-factor (NAD) requirement is also referred to as symbiotic growth (Kilian, 2005). The test can be performed on blood agar base with $5 \%$ calf blood by inoculating a blood agar plate with the test organism at a right angle to the inoculated line of a 'feeder' strain of an Acinetobacter species, Staphylococcus epidermidis or Staphylococcus aureus. The Vfactor supplied by the feeder strain will give rise to 'satellitism' of the tested isolate along the V-factor-producing isolate (Mannheim, 1989). It is important to support the V-factor requirement of such strains in further tests. These might include growth on chemically defined media with or without the addition of NAD.

CAMP is an abbreviation of the first letters of the surnames of the authors who described the test (Christie et al., 1944). The CAMP test is performed by inoculating a blood agar plate with the test organism at a right angle to an inoculated line of a $\beta$-toxinogenic strain of Staphylococcus aureus followed by overnight incubation (Christie et al., 1944). A zone of complete haemolysis resulting from a synergistic effect of the RTX toxin of the test organism and the $\beta$-toxin of Staphylococcus aureus is a positive CAMP test.

The porphyrin test documents the ability of bacteria to synthesize porphyrins (Kilian, 1976). The test is performed according to Kilian \& Frederiksen (1981) by suspending the bacteria in a solution of $\delta$ aminolaevulinic acid. Porphyrins can be detected by exposure to 'Woods light' at $360 \mathrm{~nm}$. Detection of porphobilinogens can be done by adding Kovács' reagent. The reaction is normally read after $24 \mathrm{~h}$.

The $\beta$-haemolysis test is performed on blood agar base supplemented with $5 \%$ calf blood. The reaction is normally read after $24 \mathrm{~h}$. Other sources of blood can be used. If so, the source should always be given.

Tests for glycosidases are performed with cell suspensions in peptone water and measured by reactions of the induced enzymes on glycoside equivalents coupled to nitrophenyl, allowing colorimetric determination (Kilian \& Bülow, 1976). The tests are observed for up to $24 \mathrm{~h}$. The $\beta$-glucosidase test uses NPG (4-nitrophenyl $\beta$-D-glucopyranoside). The $\beta$-galactosidase test is performed with ONPG as substrate. The $\alpha$ fucosidase test is performed with ONPF (2-nitrophenyl $\alpha$-L-fucopyranoside) (Rosco, or an alternative manufacturer). The $\alpha$-glucosidase test is carried out with PNPG (4-nitrophenyl $\alpha$-D-glucopyranoside) added as substrate. The $\beta$-glucuronidase reaction is based upon PGUA (4-nitrophenyl $\beta$-D-glucopyranosiduronic acid). The $\alpha$-mannosidase and $\alpha$-galactosidase tests might be performed with reagents from Rosco (or an alternative manufacturer). The $\beta$-xylosidase test utilizes the substrate ONPX (2-nitrophenyl $\beta$-D-xylopyranoside) (Kilian \& Bülow, 1976).

Fermentation of carbohydrates, alcohols and glucosides is carried out in a basal medium including meat extract ( $5 \mathrm{~g}$ of best quality per $1000 \mathrm{ml}$ ), peptone $(10 \mathrm{~g}$ of best quality per $1000 \mathrm{ml})$ and bromothymol blue ( $1.2 \%$ of $1: 500$ solution in water) as indicator, to which is added $0.5 \%$ of the substrate: glycerol, meso-erythritol, adonitol, (+)-Darabitol, xylitol, (+)-L-arabinose, (-)-D-arabinose, (-)-D-ribose, $(+)$-D-xylose, (-)-L-xylose, dulcitol, myo-inositol, (-)-D-mannitol, $(-)$-D-sorbitol, (-)-D-fructose, (+)-D-fucose, (-)-L-fucose, (+)-Dgalactose, $(+)$-D-glucose, $(+)$-D-mannose, $(+)$-L-rhamnose, $(-)$-Lsorbose, cellobiose, lactose, maltose, $(+)$-D-melibiose, sucrose, trehalose, (+)-D-melezitose, raffinose, dextrin, (+)-D-glycogen, inulin, (+)-D-turanose, $\beta$ - $N$ - $\mathrm{CH}_{3}$-glucosamid or the glycosides amygdalin, arbutin, gentiobiose and salicin. The tests are read after 14 days. In the case of $\mathrm{X}$ - and/or $\mathrm{V}$-factor requirements, these substrates can be added at appropriate concentrations as sterile solutions (Mannheim, 1989; Barrow \& Feltham, 1993).

\section{Acknowledgements}

Former member of the ICSP Subcommittee on the taxonomy of Pasteurellaceae Mogens Kilian and present members Patrick Blackall, Robert Davies, Olivier Gaillot, Thomas Inzana, Reinier Mutters and Niels Nørskov-Lauritsen, although not co-authors of this paper, are acknowledged for their contribution to these minimal standards.

\section{References}

Altschul, S. F., Madden, T. L., Schaffer, A. A., Zhang, J., Zhang, Z., Miller, W. \& Lipman, D. J. (1997). Gapped BLAST and PSI-BLAST: a new generation of protein database search programs. Nucleic Acids Res 25, 3389-3402.

Angen, Ø., Aalbæk, B., Falsen, E., Olsen, J. E. \& Bisgaard, M. (1997a). Relationships among strains classified with the ruminant [Pasteurella] haemolytica-complex using quantitative evaluation of phenotypic data. Zentralbl Bakteriol 285, 459-479.

Angen, Ø., Caugant, D. A., Olsen, J. E. \& Bisgaard, M. (1997b). Genotypic relationships among strains classified under the [Pasteurella] haemolytica-complex as indicated by ribotyping and multilocus enzyme electrophoresis. Zentralbl Bakteriol 286, 333-354.

Angen, Ø., Mutters, R., Caugant, D. A., Olsen, J. E. \& Bisgaard, M. (1999). Taxonomic relationships of the [Pasteurella] haemolytica complex as evaluated by DNA-DNA hybridizations and 16S rRNA sequencing with proposal of Mannheimia haemolytica gen. nov., comb. nov., Mannheimia granulomatis comb. nov., Mannheimia glucosida sp. nov., Mannheimia ruminalis sp. nov. and Mannheimia varigena sp. nov. Int J Syst Bacteriol 49, 67-86.

Angen, Ø., Ahrens, P., Kuhnert, P., Christensen, H. \& Mutters, R. (2003). Proposal of Histophilus somni gen. nov., sp. nov. for the three species incertae sedis 'Haemophilus somnus', 'Haemophilus agni' and 'Histophilus ovis'. Int J Syst Evol Microbiol 53, 1449-1456. 
Barrow, G. I. \& Feltham, R. K. A. (1993). Cowan and Steel's Manual for the Identification of Medical Bacteria, 3rd edn. Cambridge: Cambridge University Press.

Benson, D. A., Karsch-Mizrachi, I., Lipman, D. J., Ostell, J. \& Wheeler, D. L. (2006). GenBank. Nucleic Acids Res 34, D16-D20.

Bernardet, J. F., Nakagawa, Y. \& Holmes, B. (2002). Proposed minimal standards for describing new taxa of the family Flavobacteriaceae and emended description of the family. Int J Syst Evol Microbiol 52, 1049-1070.

Biberstein, E. L. \& Zinneman, K. (1982). International Committee on Systematic Bacteriology Subcommittee on the taxonomy of Haemophilus. Minutes of the meeting, 3 and 4 September 1978, Munich. Int J Syst Bacteriol 32, 244-245.

Bisgaard, M. (1993). Ecology and significance of Pasteurellaceae in animals. Zentralbl Bakteriol 279, 7-26.

Bisgaard, M., Houghton, S. B., Mutters, R. \& Stenzel, A. (1991). Reclassification of German, British and Dutch isolates of so-called Pasteurella multocida obtained from pneumonic calf lungs. Vet Microbiol 26, 115-124.

Bisgaard, M., Brown, D. J., Costas, M. \& Ganner, M. (1993). Whole cell protein profiling of actinobacillus-like strains classified as taxon 2 and taxon 3 according to Bisgaard. Zentralbl Bakteriol 279, 92-103.

Blackall, P. J., Fegan, N., Chew, G. T. I. \& Hampson, D. J. (1998). Population structure and diversity of avian isolates of Pasteurella multocida from Australia. Microbiology 144, 279-289.

Blackall, P. J., Christensen, H., Beckenham, T., Blackall, L. L. \& Bisgaard, M. (2005). Reclassification of Pasteurella gallinarum, [Haemophilus] paragallinarum, Pasteurella avium and Pasteurella volantium as Avibacterium gallinarum gen. nov., comb. nov., Avibacterium paragallinarum comb. nov., Avibacterium avium comb. nov. and Avibacterium volantium comb. nov. Int J Syst Evol Microbiol 55, 353-362.

Brenner, D. J., Krieg, N. R., Staley, J. T. \& Garrity, G. M. (editors) (2005). Bergey's Manual of Systematic Bacteriology, 2nd edn, vol. 2. New York: Springer.

Busse, H.-J., Bunka, S., Hensel, A. \& Lubitz, W. (1997). Discrimination of members of the family Pasteurellaceae based on polyamine patterns. Int J Syst Bacteriol 47, 698-708.

Catry, B., Baele, M., Opsomer, G., de Kruif, A., Decostere, A. \& Haesebrouck, F. (2004). tRNA-intergenic spacer PCR for the identification of Pasteurella and Mannheimia spp. Vet Microbiol 98, 251-260.

Cattoir, V., Lemenand, O., Avril, J.-L. \& Gaillot, O. (2006). The sodA gene as a target for phylogenetic dissection of the genus Haemophilus and accurate identification of human clinical isolates. Int $\mathrm{J} \mathrm{Med}$ Microbiol 296, 531-540.

Christensen, H. (2005). Systematics of selected members of the bacterial family Pasteurellaceae Pohl 1981 associated with animals. Doctor of Veterinary Science thesis, Department of Veterinary Pathobiology, The Royal Veterinary and Agricultural University, Copenhagen, Denmark.

Christensen, H., Bisgaard, M., Frederiksen, W., Mutters, R., Kuhnert, P. \& Olsen, J. E. (2001). Is characterization of a single isolate sufficient for valid publication of a new genus or species? Proposal on reformulation of Recommendation $30 \mathrm{~b}$ of the Bacteriological Code. Int J Syst Evol Microbiol 51, 2221-2225.

Christensen, H., Bisgaard, M. \& Olsen, J. E. (2002). Reclassification of equine isolates previously reported as Actinobacillus equuli, variants of A. equuli, Actinobacillus suis or Bisgaard taxon 11 and proposal of $A$. equuli subsp. equuli subsp. nov. and $A$. equuli subsp. haemolyticus subsp. nov. Int J Syst Evol Microbiol 52, $1569-1576$
Christensen, H., Bisgaard, M., Bojesen, A. M., Mutters, R. \& Olsen, J. E. (2003). Genetic relationships among avian isolates classified as Pasteurella haemolytica, 'Actinobacillus salpingitidis' or Pasteurella anatis with proposal of Gallibacterium anatis gen. nov., comb. nov. and description of additional genomospecies within Gallibacterium gen. nov. Int J Syst Evol Microbiol 53, 275-287.

Christensen, H., Kuhnert, P., Olsen, J. E. \& Bisgaard, M. (2004). Comparative phylogenies of the housekeeping genes atpD, infB and $r p o B$ and the 16S rRNA gene within the Pasteurellaceae. Int J Syst Evol Microbiol 54, 1601-1609.

Christensen, H., Kuhnert, P., Bisgaard, M., Mutters, R., Dziva, F. \& Olsen, J. E. (2005). Emended description of porcine [Pasteurella] aerogenes, [Pasteurella] mairii and [Actinobacillus] rossii. Int J Syst Evol Microbiol 55, 209-223.

Christie, R., Atkins, N. E. \& Munch-Petersen, E. (1944). A note on a lytic phenomenon shown by group B streptococci. Aust J Exp Biol 22, 197-200.

Cochrane, G., Aldebert, P., Althorpe, N., Andersson, M., Baker, W., Baldwin, A., Bates, K., Bhattacharyya, S., Browne P. \& other authors (2006). EMBL nucleotide sequence database: developments in 2005. Nucleic Acids Res 34, D10-D15.

Davies, R. L., MacCorquodale, R. \& Reilly, S. (2004). Characterisation of bovine strains of Pasteurella multocida and comparison with isolates of avian, ovine and porcine origin. Vet Microbiol 99, 145-158.

De Ley, J., Mannheim, W., Mutters, R., Piechulla, K., Tytgat, R., Segers, P., Bisgaard, M., Frederiksen, W., Hinz, K.-H. \& Vanhoucke, M. (1990). Inter- and intrafamilial similarities of rRNA cistrons of the Pasteurellaceae. Int J Syst Bacteriol 40, 126-137.

De Vos, P. \& Trüper, H. G. (2000). Judicial Commission of the International Committee on Systematic Bacteriology. IXth International (IUMS) Congress of Bacteriology and Applied Microbiology. Minutes of the meetings, 14, 15 and 18 August 1999, Sydney Australia. Int J Syst Evol Microbiol 50, 2239-2244.

Dewhirst, F. E., Paster, B. J., Olsen, I. \& Fraser, G. J. (1992). Phylogeny of 54 representative strains of species in the family Pasteurellaceae as determined by comparison of $16 \mathrm{~S}$ rRNA sequences. J Bacteriol 174, 2002-2013.

Escande, F., Grimont, F., Grimont, P. A. D. \& Bercovier, H. (1984). Deoxyribonucleic acid relatedness among strains of Actinobacillus spp. and Pasteurella ureae. Int J Syst Bacteriol 34, 309-315.

Euzéby, J. P. (1997). List of bacterial names with standing in nomenclature: a folder available on the Internet (URL: http:// www.bacterio.cict.fr/). Int J Syst Bacteriol 47, 590-592.

Fournier, P.-E., Suhre, K., Fournous, G. \& Raoult, D. (2006). Estimation of prokaryote genomic DNA G + C content by sequencing universally conserved genes. Int J Syst Evol Microbiol 56, 1025-1029.

Fox, G. E., Wisotzkey, J. D. \& Jurtshuk, P., Jr (1992). How close is close: $16 \mathrm{~S}$ rRNA sequence identity may not be sufficient to guarantee species identity. Int J Syst Bacteriol 42, 166-170.

Frederiksen, W. (1991). International Committee on Systematic Bacteriology Subcommittee on Pasteurellaceae and related organisms. Minutes on the meeting, 17 September 1990, Osaka, Japan. Int J Syst Bacteriol 41, 592.

Freney, J., Kloos, W. E., Hajek, V., Webster, J. A., Bes, M., Brun, Y. \& Vernozy-Rozand, C. (1999). Recommended minimal standards for description of new staphylococcal species. Int J Syst Bacteriol 49, 489-502.

Friis-Møller, A., Christensen, J. J., Fussing, V., Hesselbjerg, A., Christiansen, J. \& Bruun, B. (2001). Clinical significance and taxonomy of Actinobacillus hominis. J Clin Microbiol 39, 930935. 
Fussing, V., Paster, B. J., Dewhirst, F. E. \& Poulsen, L. K. (1998). Differentiation of Actinobacillus pleuropneumoniae strains by sequence analysis of $16 \mathrm{~S}$ rDNA and ribosomal intergenic regions, and development of a species specific oligonucleotide for in situ detection. Syst Appl Microbiol 21, 408-418.

Gautier, A. L., Dubois, D., Escande, F., Avril, J.-L., Trieu-Cuot, P. \& Gaillot, O. (2005). Rapid and accurate identification of human isolates of Pasteurella and related species by sequencing the $\operatorname{sodA}$ gene. J Clin Microbiol 43, 2307-2314.

Gevers, D., Cohan, F. M., Lawrence, J. G., Spratt, B. G., Coenye, T., Feil, E. J., Stackebrandt, E., Van de Peer, Y., Vandamme, P. \& other authors (2005). Opinion: re-evaluating prokaryotic species. Nat Rev Microbiol 3, 733-739.

Gillis, M., Vandamme, P., De Vos, P., Swings, J. \& Kersters, K. (2005). Polyphasic taxonomy. In Bergey's Manual of Systematic Bacteriology, 2nd edn, vol. 2, pp. 43-48. Edited by D. J. Brenner, N. R. Krieg, J. T. Staley \& G. M. Garrity. New York: Springer.

Graham, P. H., Sadowsky, M. J., Keyser, H. H., Barnet, Y. M., Bradley, R. S., Cooper, J. E., De Ley, J., Jarvis, B. D. W., Roslycky, E. B. \& other authors (1991). Proposed minimal standards for the description of new genera and species of root- and stem-nodulating bacteria. Int J Syst Bacteriol 41, 582-587.

Hanage, W. P., Fraser, C. \& Spratt, B. G. (2005). Fuzzy species among recombinogenic bacteria. BMC Biol 3, 6 .

Harte, N., Silventoinen, V., Quevillon, E., Robinson, S., Kallio, K., Fustero, X., Patel, P., Jokinen, P. \& Lopez, R. (2004). Public webbased services from the European Bioinformatics Institute. Nucleic Acids Res 32, W3-W9.

Kainz, A., Lubitz, W. \& Busse, H. J. (2000). Genomic fingerprints, ARDRA profiles and quinone systems for classification of Pasteurella sensu stricto. Syst Appl Microbiol 23, 494-503.

Kilian, M. (1976). A taxonomic study of the genus Haemophilus, with the proposal of a new species. J Gen Microbiol 93, 9-62.

Kilian, M. (2005). Genus Haemophilus Winslow, Broadhurst, Buchanan, Krumwiede, Rogers and Smith 1917, 561 ${ }^{\mathrm{AL}}$. In Bergey's Manual of Systematic Bacteriology, 2nd edn, vol. 2, pp. 883-904. Edited by D. J. Brenner, N. R. Krieg, J. T. Staley \& G. M. Garrity. New York: Springer.

Kilian, M. \& Bülow, P. (1976). Rapid diagnosis of Enterobacteriaceae. Acta Pathol Microbiol Scand Sect B 84, 245-251.

Kilian, M. \& Frederiksen, W. (1981). Appendix. Identification tables for the Haemophilus-Pasteurella-Actinobacillus group. In Haemophilus, Pasteurella and Actinobacillus, pp. 281-290. Edited by M. Kilian, W. Frederiksen \& E. Biberstein. London: Academic Press.

Korczak, B., Christensen, H., Emler, S., Frey, J. \& Kuhnert, P. (2004). Phylogeny of the family Pasteurellaceae based on rpoB sequences. Int J Syst Evol Microbiol 54, 1393-1399.

Kuhnert, P. \& Christensen, H. (2006). International Committee on Systematics of Prokaryotes Subcommittee on the taxonomy of the Pasteurellaceae. Minutes of the meetings, 25 July 2005, San Francisco, CA, USA. Int J Syst Evol Microbiol 56, 675-676.

Kuhnert, P. \& Korczak, B. M. (2006). Prediction of whole-genome DNA-DNA similarity, determination of $\mathrm{G}+\mathrm{C}$ content and phylogenetic analysis within the family Pasteurellaceae by multilocus sequence analysis (MLSA). Microbiology 152, 2537-2548.

Kuhnert, P., Korczak, B., Falsen, E., Straub, R., Hoops, A., Boerlin, P., Frey, J. \& Mutters, R. (2004). Nicoletella semolina gen. nov., sp. nov., a new member of Pasteurellaceae isolated from horses with airway disease. J Clin Microbiol 42, 5542-5548.

Kuhnert, P., Korczak, B. M., Christensen, H. \& Bisgaard, M. (2007). Emended description of Actinobacillus capsulatus Arseculeratne 1962, $38^{\mathrm{AL}}$. Int J Syst Evol Microbiol 57 (in press).
Lapage, S. P. \& Redway, K. F. (1974). Preservation of bacteria with notes on other micro-organisms. Public Health Laboratory Service Monograph Series 7. London: Her Majesty's Stationary Office.

Lapage, S. P., Sneath, P. H. A., Lessel, E. F., Skerman, V. B. D., Seeliger, H. P. R. \& Clark, W. A. (editors) (1992). International Code of Nomenclature of Bacteria (1990 Revision). Bacteriological Code. Washington, DC: American Society for Microbiology.

Lessel, E. F. (1971). Judicial Commission of the International Committee on Nomenclature of Bacteria. Minutes of meeting, 5 August 1970. Int J Syst Bacteriol 21, 100-103.

Ludwig, W. \& Klenk, H.-P. (2001). Overview: a phylogenetic backbone and taxonomic framework for procaryotic systematics. In Bergey's Manual of Systematic Bacteriology, 2nd edn, vol. 1, pp. 49-65. Edited by D. R. Boone, R. W. Castenholz \& G. M. Garrity. New York: Springer.Int J Syst Evol Microbiol 57 (in press).

Ludwig, W., Strunk, O., Westram. R., Richter, L., Meier, H., Yadhukumar Buchner, A., Lai, T., Steppi S. \& other authors (2004). ARB: a software environment for sequence data. Nucleic Acids Res 32, 1363-1371.

Maiden, M., Bygraves, J. A., Feil, E., Morelli, G., Russell, J. E., Urwin, R., Zhang, Q., Zhou, J., Zurth, K. \& other authors (1998). Multilocus sequence typing: a portable approach to the identification of clones within populations of pathogenic microorganisms. Proc Natl Acad Sci U S A 95, 3140-3145.

Mannheim, W. (1989). Isolierung und Identifiziering von Pasteurellaceae (Haemophilus, Pasteurella, Actinobacillus und verwandte Taxa). Zentralbl Bakteriol 272, 87-109 (in German).

Meats, E., Feil, E. J., Stringer, S., Cody, A. J., Goldstein, R., Kroll, J. S., Popovic, T. \& Spratt, B. G. (2003). Characterization of encapsulated and noncapsulated Haemophilus influenzae and determination of phylogenetic relationships by multilocus sequence typing. J Clin Microbiol 41, 1623-1636.

Møller, K., Fussing, V., Grimont, P. A. D., Paster, B. J., Dewhirst, F. E. \& Kilian, M. (1996). Actinobacillus minor sp. nov., Actinobacillus porcinus sp. nov., and Actinobacillus indolicus sp. nov., three new $\mathrm{V}$ factor-dependent species from the respiratory tract of pigs. Int J Syst Bacteriol 46, 951-956.

Mutters, R., Ihm, P., Pohl, S., Frederiksen, W. \& Mannheim, W. (1985). Reclassification of the genus Pasteurella Trevisan 1887 on the basis of DNA homology with proposals for the new species Pasteurella dagmatis, Pasteurella canis, Pasteurella stomatis, Pasteurella anatis, and Pasteurella langaa. Int J Syst Bacteriol 35, 309-322.

Mutters, R., Mannheim, W. \& Bisgaard, M. (1989). Taxonomy of the group. In Pasteurella and Pasteurellosis, pp. 3-34. Edited by C. Adlam \& J. M. Rutter. London: Academic Press.

Mutters, R., Mouahid, M., Engelhard, E. \& Mannheim, W. (1993). Characterization of the family Pasteurellaceae on the basis of cellular lipids and carbohydrates. Zentralbl Bakteriol 279, 104-113.

Nørskov-Lauritsen, N. \& Kilian, M. (2006). Reclassification of Actinobacillus actinomycetemcomitans, Haemophilus aphrophilus, Haemophilus paraphrophilus and Haemophilus segnis as Aggregatibacter actinomycetemcomitans gen. nov., comb. nov., Aggregatibacter aphrophilus comb. nov. and Aggregatibacter segnis comb. nov., and emended description of Aggregatibacter aphrophilus to include $\mathrm{V}$ factor-dependent and $\mathrm{V}$ factor-independent isolates. Int J Syst Evol Microbiol 56, 2135-2146.

Nørskov-Lauritsen, N., Christensen, H., Okkels, H., Kilian, M. \& Bruun, B. (2004). Delineation of the genus Actinobacillus by comparison of partial infB sequences. Int J Syst Evol Microbiol 54, 635-644. 
Nørskov-Lauritsen, N., Bruun, B. \& Kilian, M. (2005). Multilocus sequence phylogenetic study of the genus Haemophilus with description of Haemophilus pittmaniae sp. nov. Int J Syst Evol Microbiol 55, 449-456.

Okubo, K., Sugawara, H., Gojobori, T. \& Tateno, Y. (2006). DDBJ in preparation for overview of research activities behind data submissions. Nucleic Acids Res 34, D6-D9.

Olsen, I. (1993). Recent approaches to the chemotaxonomy of the Actinobacillus-Haemophilus-Pasteurella group (family Pasteurellaceae). Oral Microbiol Immunol 8, 327-336.

Olsen, I., Dewhirst, F. E., Paster, B. J. \& Busse, H.-J. (2005). Family Pasteurellaceae. In Bergey's Manual of Systematic Bacteriology, 2nd edn, vol. 2, pp. 851-856. Edited by D. J. Brenner, N. R. Krieg, J. T. Staley \& G. M. Garrity. New York: Springer.

Osawa, R., Rainey, F., Fujisawa, T., Lang, E., Busse, H. J., Walsh, T. P. \& Stackebrandt, E. (1995). Lonepinella koalarum gen. nov., sp. nov., a new tannin-protein complex degrading bacterium. Syst Appl Microbiol 18, 368-373.

Pohl, S. (1979). Reklassifizierung der gattung Actinobacillus Brumpt 1910, Haemophilus Winslow et al. 1971 und Pasteurella Trevisan 1887 anhand phänotypischer und molekularer daten, insbesondere der DNSverwandtschaften bei DNS:DNS-hybridisierung in vitro und vorschlag einer neuen familie, Pasteurellaceae. Inaug. Diss. Phillips-Universität Marburg/Lahn. Mauersberger, Marburg, Germany (in German).

Pohl, S. (1981). Family Pasteurellaceae fam. nov. In Validation of the Publication of New Names and New Combinations Previously Effectively Published Outside the IJSB, List no. 7. Int J Syst Bacteriol 31, 382-383.

Rice, P., Longden, I. \& Bleasby, A. (2000). EMBOss: the European Molecular Biology Open Software Suite. Trends Genet 16, 276-277.

Saddler, G. S. (2005). International Committee on Systematics of Prokaryotes; Xth International (IUMS) Congress of Bacteriology and Applied Microbiology; Minutes of the meetings, 28 and 30 July 2002, Paris, France. Int J Syst Evol Microbiol 55, 533-537.

Schmid, H., Hartung, M. \& Hellmann, E. (1991). Crossed immunoelectrophoresis applied to representative strains from 11 different Pasteurella species under taxonomic aspects. Zentralbl Bakteriol 275, 16-27.

Skerman, V. B. D., McGowan, V. \& Sneath, P. H. A. (editors) (1980). Approved Lists of Bacterial Names. Int J Syst Bacteriol 30, 225-420.

Sneath, P. H. A. \& Stevens, M. (1985). A numerical taxonomic study of Actinobacillus, Pasteurella and Yersinia. J Gen Microbiol 131, 2711-2738.
Snipes, K. P. \& Biberstein, E. L. (1982). Pasteurella testudinis sp. nov. a parasite of desert tortoises (Gopherum agassizi). Int J Syst Bacteriol 32, 201-210.

Stackebrandt, E. (1992). Unifying phylogeny and phenotypic diversity. In The Prokaryotes, 2nd edn, vol. 1, pp. 19-47. Edited by A. Balows, H. G. Trüper, M. Dworkin, W. Harder \& K. H. Schleifer. New York: Springer.

Stackebrandt, E. \& Goebel, B. M. (1994). Taxonomic note: a place for DNA-DNA reassociation and $16 \mathrm{~S}$ rRNA sequence analysis in the present species definition in bacteriology. Int J Syst Bacteriol 44, 846-849.

Stackebrandt, E., Frederiksen, W., Garrity, G. M., Grimont, P. A. D., Kämpfer, P., Maiden, M. C. J., Nesme, X., Rosselló-Mora, R., Swings, J. \& other authors (2002). Report of the ad hoc committee for the re-evaluation of the species definition in bacteriology. Int J Syst Evol Microbiol 52, 1043-1047.

Tabor, C. W. \& Tabor, H. (1985). Polyamines in microorganisms. Microbiol Rev 49, 81-99.

Thompson, J. D., Gibson, T. J., Plewniak, F., Jeanmougin, F. \& Higgins, D. G. (1997). The CLUSTAL_X windows interface: flexible strategies for multiple sequence alignment aided by quality analysis tools. Nucleic Acids Res 25, 4876-4882.

Thornton, J. M., Austin, D. A., Austin, B. \& Powell, R. (1999). Small subunit rRNA gene sequences of Aeromonas salmonicida subsp. smithia and Haemophilus piscium reveal pronounced similarities with A. salmonicida subsp. salmonicida. Dis Aquat Organ 29, 155-158.

Tindall, B. J. (1999). Misunderstanding the Bacteriological Code. Int J Syst Bacteriol 49, 1313-1316.

Vandamme, P., Pot, B., Gillis, M., De Vos, P., Kersters, K. \& Swings, J. (1996). Polyphasic taxonomy, a consensus approach to bacterial systematics. Microbiol Rev 60, 407-438.

Wauters, G. \& Mair, N. S. (1982). International Committee on Systematic Bacteriology Subcommittee on the taxonomy of Pasteurella, Francisella, and Yersinia. Minutes of the meeting, 5 and 6 October 1979, Institut Pasteur, Paris. Int J Syst Bacteriol 32, 144-145.

Wheeler, D. L., Church, D. M., Edgar, R., Federhen, S., Helmberg, W., Madden, T. L., Pontius, J. U., Schuler, G. D., Schriml, L. M. \& other authors (2004). Database resources of the National Center for Biotechnology Information: update. Nucleic Acids Res 32, D35-D40.

Zeigler, D. R. (2003). Gene sequences useful for predicting relatedness of whole genomes in bacteria. Int J Syst Evol Microbiol 53, 1893-1900. 